\title{
High-precision quasi-continuous atmospheric greenhouse gas measurements at Trainou tower (Orléans forest, France)
}

\author{
M. Schmidt ${ }^{1, *}$, M. Lopez ${ }^{1}$, C. Yver Kwok ${ }^{1}$, C. Messager ${ }^{1}$, M. Ramonet ${ }^{1}$, B. Wastine ${ }^{1}$, C. Vuillemin ${ }^{1}$, F. Truong ${ }^{1}$, \\ B. Gal ${ }^{1}$, E. Parmentier ${ }^{2}$, O. Cloué ${ }^{3}$, and P. Ciais ${ }^{1}$ \\ ${ }^{1}$ Laboratoire des Sciences du Climat et de 1'Environnement (LSCE/IPSL), Unité Mixte de Recherche (CEA-CNRS-UVSQ), \\ Gif-sur-Yvette, France \\ ${ }^{2}$ IPGP, Institut de Physique du Globe de Paris, Observatoire magnétique de Chambon la Forêt, Chambon la Forêt, France \\ ${ }^{3}$ IRFU, Institut de recherche sur les lois fondamentales de l'Univers, CEA, Saclay, France \\ *now at: Institut für Umweltphysik, University of Heidelberg, Germany
}

Correspondence to: M. Schmidt (martina.schmidt@iup.uni-heidelberg.de)

Received: 28 November 2013 - Published in Atmos. Meas. Tech. Discuss.: 23 January 2014

Revised: 26 May 2014 - Accepted: 29 May 2014 - Published: 30 July 2014

\begin{abstract}
Results from the Trainou tall tower measurement station installed in 2006 are presented for atmospheric measurements of $\mathrm{CO}_{2}, \mathrm{CH}_{4}, \mathrm{~N}_{2} \mathrm{O}, \mathrm{SF}_{6}, \mathrm{CO}, \mathrm{H}_{2}$ mole fractions and radon-222 activity. Air is sampled from four sampling heights $(180,100,50$ and $5 \mathrm{~m})$ of the Trainou $200 \mathrm{~m}$ television tower in the Orléans forest in France $\left(47^{\circ} 57^{\prime} 53^{\prime \prime} \mathrm{N}\right.$, $2^{\circ} 06^{\prime} 45^{\prime \prime} \mathrm{E}, 131 \mathrm{~m}$ a.s.l.). The station is equipped with a custom-built $\mathrm{CO}_{2}$ analyser (CARIBOU), which is based on a commercial non-dispersive, infrared (NDIR) analyser (Licor 6252), and a coupled gas chromatography (GC) system equipped with an electron capture detector (ECD) and a flame ionization detector (FID) (HP6890N, Agilent) and a reduction gas detector (PP1, Peak Performer). Air intakes, pumping and air drying system are shared between the CARIBOU and the GC systems. The ultimately achieved short-term repeatability (1 sigma, over several days) for the $\mathrm{GC}$ system is $0.05 \mathrm{ppm}$ for $\mathrm{CO}_{2}, 1.4 \mathrm{ppb}$ for $\mathrm{CH}_{4}, 0.25 \mathrm{ppb}$ for $\mathrm{N}_{2} \mathrm{O}, 0.08 \mathrm{ppb}$ for $\mathrm{SF}_{6}, 0.88 \mathrm{ppb}$ for $\mathrm{CO}$ and 3.8 for $\mathrm{H}_{2}$. The repeatability of the CARIBOU $\mathrm{CO}_{2}$ analyser is $0.06 \mathrm{ppm}$. In addition to the in situ measurements, weekly flask sampling is performed, and flask air samples are analysed at the Laboratoire des Sciences du Climat et de l'Environnement (LSCE) central laboratory for the same species as well for stable isotopes of $\mathrm{CO}_{2}$. The comparison between in situ measurements and the flask sampling showed averaged differences of $0.08 \pm 1.40 \mathrm{ppm}$ for $\mathrm{CO}_{2}$, $0.7 \pm 7.3 \mathrm{ppb}$ for $\mathrm{CH}_{4}, 0.6 \pm 0.6 \mathrm{ppb}$ for $\mathrm{N}_{2} \mathrm{O}, 0.01 \pm 0.10 \mathrm{ppt}$
\end{abstract}

for $\mathrm{SF}_{6}, 1.5 \pm 5.3 \mathrm{ppb}$ for $\mathrm{CO}$ and $4.8 \pm 6.9 \mathrm{ppb}$ for $\mathrm{H}_{2}$ for the years 2008-2012.

At Trainou station, the mean annual increase rates from 2007 to 2011 at the $180 \mathrm{~m}$ sampling height were $2.2 \mathrm{ppm} \mathrm{yr}^{-1}$ for $\mathrm{CO}_{2}, 4 \mathrm{ppb} \mathrm{yr}^{-1}$ for $\mathrm{CH}_{4}, 0.78 \mathrm{ppb} \mathrm{yr}^{-1}$ for $\mathrm{N}_{2} \mathrm{O}$ and $0.29 \mathrm{ppt} \mathrm{yr}^{-1}$ for $\mathrm{SF}_{6}$. For all species, the $180 \mathrm{~m}$ sampling level showed the smallest diurnal variation. Mean diurnal gradients between the $50 \mathrm{~m}$ and the $180 \mathrm{~m}$ sampling level reached up to $30 \mathrm{ppm} \mathrm{CO}_{2}, 15 \mathrm{ppm} \mathrm{CH}_{4}$ or $0.5 \mathrm{ppb} \mathrm{N}_{2} \mathrm{O}$ during nighttime whereas the mean gradients are smaller than $0.5 \mathrm{ppm}$ for $\mathrm{CO}_{2}$ and $1.5 \mathrm{ppb}$ for $\mathrm{CH}_{4}$ during afternoon.

\section{Introduction}

The atmospheric greenhouse gas (GHG) measurement group (RAMCES) at the Laboratoire des Sciences du Climat et de l'Environnement (LSCE) in Gif-sur-Yvette is currently running a global network of 8 in situ stations and 13 flask sampling sites at 12 fixed surface sites, and one on board a small aircraft. At LSCE the air samples are analysed for $\mathrm{CO}_{2}$ isotopes $\left(\delta^{13} \mathrm{C}\right.$ and $\left.\delta^{18} \mathrm{O}\right)$ and for $\mathrm{CO}_{2}, \mathrm{CH}_{4}, \mathrm{~N}_{2} \mathrm{O}$, $\mathrm{SF}_{6}, \mathrm{CO}$ and $\mathrm{H}_{2}$ mole fractions. The RAMCES $\mathrm{CO}_{2}$ and radon-222 monitoring program was initiated in 1980 at the Île Amsterdam observatory (Gaudry et al., 1992; Ramonet and Monfray, 1996) and was extended at Mace Head, Ireland in 1992 (Biraud et al., 2000, 2002) and at two further sites in France (Gif-sur-Yvette and Puy de Dome) in 2011. The three 
western European sites reflect different environments from a marine site occasionally influenced by long range transport over Europe (Mace Head), to sites which are more influenced by rural (Puy de Dôme) and urban activities (Gif-sur-Yvette).

Europe has a long history of atmospheric $\mathrm{CO}_{2}$ monitoring at continental stations, in which the LSCE network participates. To avoid the influence of local trace gas sources, mountain stations such as Schauinsland (Germany), Mt Cimone (Italy) or Puy de Dôme (France) were traditionally chosen, and a data selection is performed at these sites to obtain a greenhouse gas record reflecting regional scale continental sources and sinks (Schmidt et al., 2003; Cundari et al., 1990). However, such measurements are difficult to reproduce by atmospheric transport models due to the influence of topography on air mass transport and mixing (Geels et al., 2007). Consequently, other approaches needed to be developed to complement regional scale emission inventories, through airborne measurements or high towers that avoid being strongly influenced by topography. The frequency of the airborne measurements is still a limiting factor, as well as the bias towards good weather conditions (Stephens et al., 2007). A very promising approach is therefore to establish new stations on tall towers ( $>100 \mathrm{~m})$ which are used as television transmission towers (Bakwin et al., 1998; Haszpra et al., 2001). Gloor et al. (2001) showed that the concentration footprint of the Wisconsin $500 \mathrm{~m}$ tall tower is of the order of $10^{6} \mathrm{~km}^{2}$.

In the framework of the European projects CHIOTTO (Continuous HIgh-precisiOn Tall Tower Observations of greenhouse gases, http://www.chiotto.org) and CarboEurope IP (http://www.carboeurope.org), eight European tall towers have been equipped or upgraded with high precision measurements systems for continuous greenhouse gas monitoring (Vermeulen et al., 2007). Results and instrumental setups are published by Thompson et al. (2009), Popa et al. (2010), Vermeulen et al. (2011). Our group has equipped a new station within Orléans Forest, called Trainou tower, with instrumentation for atmospheric $\mathrm{CO}_{2}, \mathrm{CH}_{4}, \mathrm{CO}, \mathrm{N}_{2} \mathrm{O}, \mathrm{SF}_{6}, \mathrm{H}_{2}$ and radon-222 measurements. The measurements at four levels of Trainou tower $(5,50,100,180 \mathrm{~m})$ are completed by regular airborne measurements between 100 and $3000 \mathrm{~m}$ altitude close to the tower. In the framework of the TCCON (Total Carbon Column Observing) network, IUP Bremen installed a ground-based Fourier transform spectrometer (FTS) to analyse the column abundances of $\mathrm{CO}_{2}, \mathrm{CH}_{4}$ and $\mathrm{N}_{2} \mathrm{O}$ (Messerschmidt et al., 2011).

In the following chapters of the paper, we present the station location, the instrumental setup, data transmission, quality control and the time series of atmospheric $\mathrm{CO}_{2}, \mathrm{~N}_{2} \mathrm{O}$, $\mathrm{CH}_{4}, \mathrm{SF}_{6}, \mathrm{CO} \mathrm{H}_{2}$, and ${ }^{222} \mathrm{Rn}$ measurements.

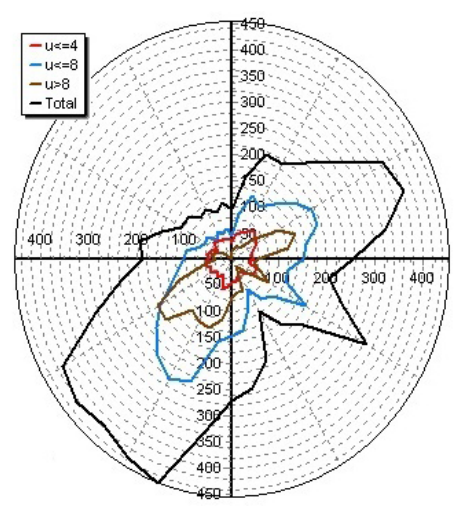

Figure 1. Wind rose of Trainou station $(180 \mathrm{~m})$ for four different wind classes calculated with Trajectory Viewer 1.1 developed at ECN (Energy Research Centre of the Netherlands, http://www.ecn. $\mathrm{nl} /$ ) and from model FLEXTRA (Stohl et al., 2005) for the year 2005 .

\section{Site description}

The station (Trainou tower, TRN) for atmospheric greenhouse gas observation is located in the "Centre" region in France $\left(47^{\circ} 57^{\prime} 53^{\prime \prime} \mathrm{N}, 2^{\circ} 06^{\prime} 45^{\prime \prime} \mathrm{E}, 131 \mathrm{~m}\right.$ above sea level (a.s.l.) at a $200 \mathrm{~m}$ transmitter mast. We setup sampling at four levels on this tower at $5 \mathrm{~m}$ (TR0), $50 \mathrm{~m}$ (TR1), $100 \mathrm{~m}$ (TR2) and $180 \mathrm{~m}$ (TR3). Trainou station is about $15 \mathrm{~km}$ northeast of the city of Orléans (116000 habitants) and about $100 \mathrm{~km}$ south of Paris. Five small villages ( $<2000$ habitants) are located nearby the station. In the surroundings of the station, the area is covered by forest $(30 \%)$ and agriculture fields (50 \%) (INSEE 2008, National Institute of Statistics and Economic Studies, 2008, http://www.insee.fr).

Using the anthropogenic emissions estimated from bottom up studies for the Centre region for 2000 (CITEPA, 2005, http://www.citepa.org), we can identify the main local and regional sources by sector. For $\mathrm{CO}_{2}$, the three main emission sectors are transport, agriculture and households. More than $50 \%$ of the $\mathrm{CH}_{4}$ emissions in this region are released by livestock production (dairy cows) and about $25 \%$ from waste treatment (landfills). For $\mathrm{N}_{2} \mathrm{O}$, the agriculture sector (fertiliser application in croplands) contributes more than $90 \%$ of the anthropogenic emissions in this region.

Prior to installation, we studied the wind direction and velocity distribution using the Trajectory Viewer 1.1 developed at ECN (Energy Research Centre of the Netherlands, http://www.ecn.nl/) and the model output from the FLEXible PARTicle dispersion model (FLEXPART) (Stohl et al., 2005). We do not show the real wind measurements here because we have only one wind sensor at the tower and our measured wind direction and velocity are biased by the wind shadow of the tower. Figure 1 shows that the dominating wind direction at the $180 \mathrm{~m}$ level is southwest followed by northeast winds. The distribution of the wind velocity shows maximum value at $6 \mathrm{~m} \mathrm{~s}^{-1}$. 


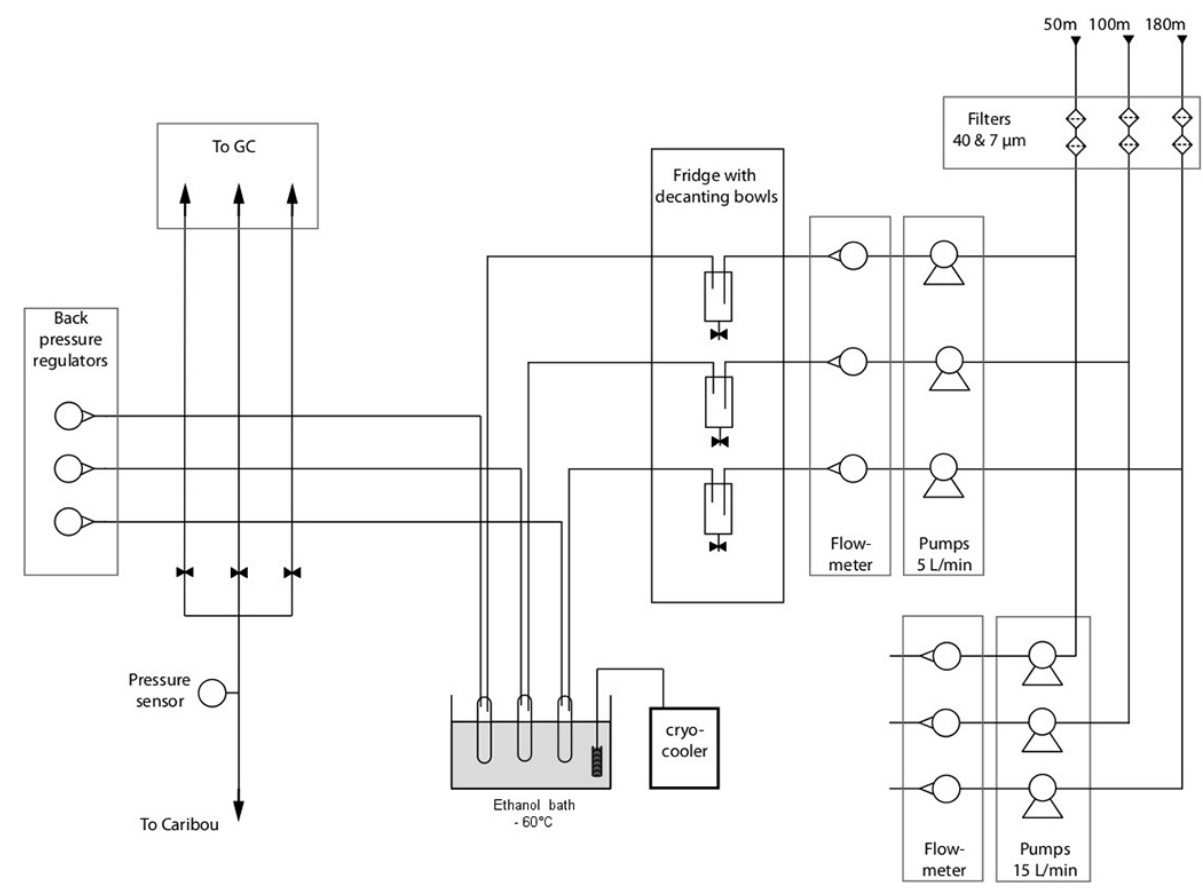

Figure 2. Schematic view of the air inlet and drying system controlled by the CARIBOU software. The dried air is used for GC and CARIBOU analysis.

\section{Measurement systems}

The atmospheric measurement station at Trainou tower consists of a combined air inlet system piloted by the custommade $\mathrm{CO}_{2}$ instrument (CARIBOU), a coupled GC analyser system for $\mathrm{CO}_{2}, \mathrm{CH}_{4}, \mathrm{~N}_{2} \mathrm{O}, \mathrm{SF}_{6}, \mathrm{CO}$ and $\mathrm{H}_{2}$, a radon-222 analyser and a flask sampler unit. In the following chapters, these five parts are described in detail. Meteorological sensors (see Sect. 3.4) and seven independent inlet lines (DEKABON 1300, 1/2" o.d.) are installed on the tower. Three inlet lines are placed at the $180 \mathrm{~m}$ level, one at the $100 \mathrm{~m}$, two at $50 \mathrm{~m}$ level and one at the $5 \mathrm{~m}$ level. For radon- 222 gas measurements, a $65 \mathrm{~mm}$ inner diameter rigid tubing is installed at the $180 \mathrm{~m}$ level. The inlet lines are transferred to the container, which houses the measurement systems.

\subsection{Air inlet and drying system}

The pumping and air drying system is controlled by the CARIBOU $\mathrm{CO}_{2}$ analyser software (see below). It consists of three identical branches of pumps and cooling traps for the 50, 100 and $180 \mathrm{~m}$ levels, which allows dried air from each level to be delivered to the analysing instruments at any time (Fig. 2). Therefore we are able to analyse all three levels at least once every $30 \mathrm{~min}$, without risk of incomplete flushing of air from the level which was passed before. The three air sampling lines are flushed constantly with $15 \mathrm{~L}$ of air $\mathrm{min}^{-1}$ by the primary pumps (Neuberger N815KNE). To protect the pumps, two filters (40 and $7 \mu \mathrm{m}$, TF series from Swagelok) are installed. Depending on the meteorological conditions, the filters need to be changed at least every six months. From each inlet line, a secondary pump (Neuberger N86KTE) collects an air flow of $5 \mathrm{~L} \mathrm{~min}^{-1}$, which is then dried in two steps. First, the air passes through a glass trap (decanting bowl $120 \mathrm{~mL}$ ), which is hosted in a commercial refrigerator kept at $5{ }^{\circ} \mathrm{C}$ in order to remove the main water content from air. To remove condensed water, the traps are evacuated automatically once a day. In a second step, air is further dried by passing through $335 \mathrm{~mL}$ glass traps cooled in an ethanol bath to $-60^{\circ} \mathrm{C}$ using an cryogenic cooler (Thermo Neslab CC-65). The cooling traps are filled with glass beads to increase the surface area for water vapour condensation. These cooling traps are changed once per week by a technician who maintains the station regularly. This setup allows us to provide dried air with a dew point of less than $-50^{\circ} \mathrm{C}$ to the analysing instruments.

\subsection{In situ $\mathrm{CO}_{2}$ analyser (CARIBOU)}

LSCE and CEA/IRFU (Institute of Research into the Fundamental Laws of the Universe) developed new robust $\mathrm{CO}_{2}$ continuous monitoring stations, named CARIBOU. Within the RAMCES network, four of these stations have been installed. The first one was installed at Biscarrosse, France (inlet at $116 \mathrm{~m}$ a.s.1.) in May 2005, the second one at Hanle, India (4517 ma.s.l.) in August 2006 and the third one at Trainou tower, France. Finally, in summer 2007, a fourth one was installed at Ivittuut, Greenland. 


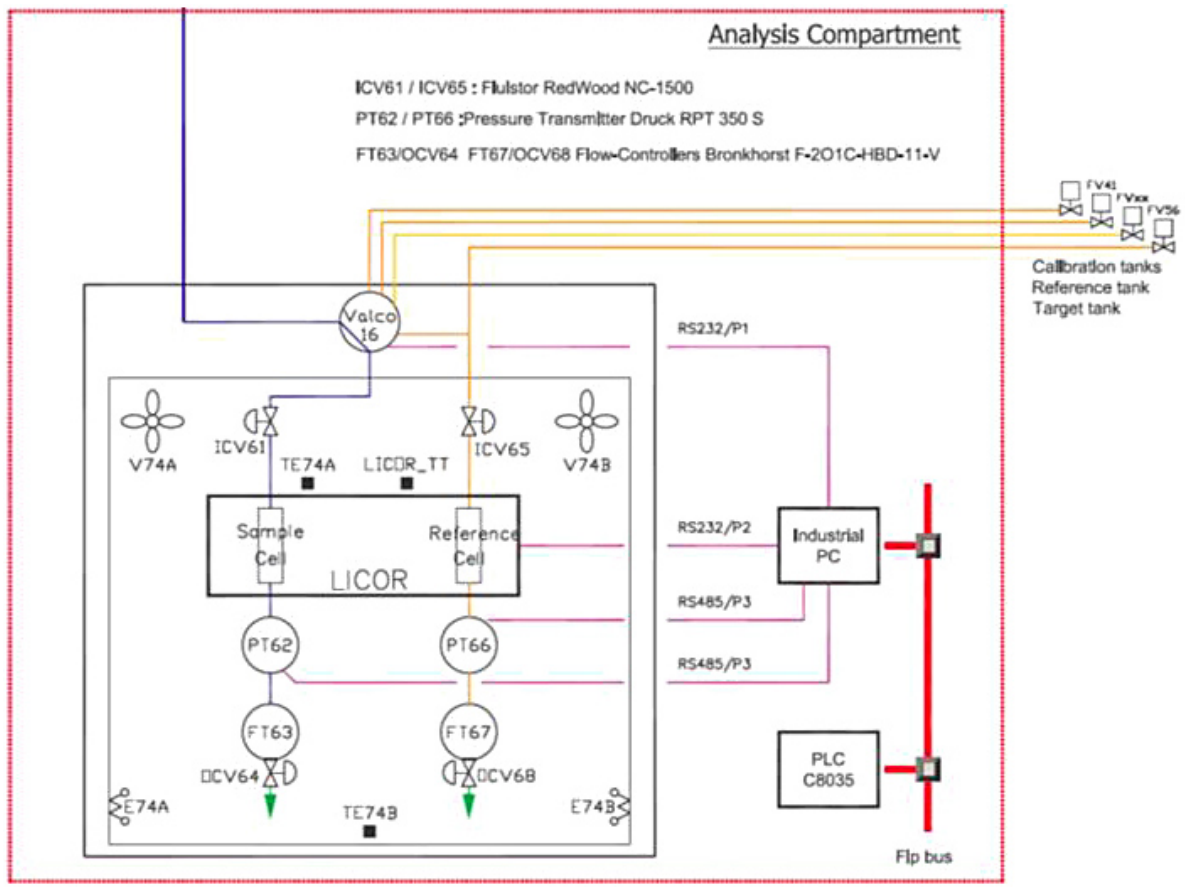

Figure 3. Schematic of CARIBOU $\mathrm{CO}_{2}$ analyser component.

The CARIBOU systems are designed to make high precision measurements (short-term repeatability of the order of $\pm 0.01 \mathrm{ppm}$ ), with high hardware reliability, and require low maintenance. The design also allows fully remote control, automated data retrieval and online display capability.

The CARIBOU system consists of two main subsystems: (a) an analysis unit which includes a commercial nondispersive, infrared (NDIR) gas analyser (LI-6252, LI-COR, Lincoln, Nebraska, USA), pressure, flow and temperature regulators controlled by a programmable logic controller (PLC), and an industrial PC used to configure and control the equipment; (b) a pumping unit, which includes the pumps for three air inlets, and a refrigerator for preliminary drying of the air to be analysed (see Sect. 3.1).

The CARIBOU design is based on the CSIRO (Commonwealth Scientific and Industrial Research Organisation, Melbourne, Australia) Loflo $\mathrm{CO}_{2}$ analyser (Da Costa and Steele, 1997). A schematic view of the system is shown in Fig. 3. The CARIBOU regulates the flow in the sample and reference cells $\left(20.00 \pm 0.03 \mathrm{~mL} \mathrm{~min}^{-1}\right)$ and the pressure inside the cells at $1080.00 \pm 0.03$ mbar with a combination of four flow-controllers (Redwood Fluistor NC-1500 and Bronkhorst F201CHBD11V) piloted by fuzzy logic algorithms. The box containing the NDIR analyser and the hardware necessary to regulate the gas flow and the pressure is thermally regulated. Moreover, there is an additional temperature control of the NDIR cells themselves $\left(40.00 \pm 0.05^{\circ} \mathrm{C}\right)$. The thermal and pressure control of the instrument minimize the drift of the NDIR analyser of $1 \mathrm{ppm}$ per day specified
Table 1. Parameters of pressure, temperature and gas flow regulation for the CARIBOU $\mathrm{CO}_{2}$ analyser.

\begin{tabular}{ll}
\hline Licor Cell pressure regulation & $1080.00 \pm 0.03 \mathrm{mbar}$ \\
\hline Thermal regulation & $40.00 \pm 0.05^{\circ} \mathrm{C}$ \\
Gas flow regulation & $20.00 \pm 0.03 \mathrm{~mL} \mathrm{~min}^{-1}$ \\
\hline
\end{tabular}

by the manufacturer (Li-6252 Instruction manual) to approximately $0.07 \mathrm{ppm}$ per day. In addition, we analyse the reference gas for $10 \mathrm{~min}$ per hour in analysis cell, and use these results to correct for the instrument drift. After drift correction we obtain a residual drift of the order of $1 \mathrm{ppb}$ per day allowing a full-span calibrations to occur once per week. A low flow of $20 \mathrm{~mL} \mathrm{~min}^{-1}$ and the weekly calibration frequency allows the calibration gas tank to last more than 10 years. The system is implemented by a 16 position micro-electric valve (Valco Vici) to select the gas to be measured (ambient air, calibration gases, etc.). The parameters for temperature and pressure regulation are summarized in Table 1.

\subsubsection{Online data transmission and remote controlling}

The CARIBOU unit has its own control system with an internet link to the LSCE laboratory (Gif-sur-Yvette) which allows remote supervision, configuration and maintenance. The raw data are downloaded automatically every day (or more frequently if needed) by a central computer at LSCE, which allows for database operations. This computer is also 
in charge of daily tasks such as checking station health. It triggers alarms or warnings in case any abnormal conditions are detected, such as poor pressure or temperature regulation. Remote controlling further allows the user to have full access to switching of pumps and valves, the regulation of temperature set points and flow rates and the duration of gas analysis. Measurement sequences are created via an built-in sequencer and most of the data $\left(\mathrm{CO}_{2}\right.$ mole fraction, pressure, temperature, valves state, etc.) can be plotted on screen for a rapid diagnostic.

\subsubsection{Calibration and quality control}

At Trainou station, the CARIBOU calibration of the full span of the instrument is carried out every eights days using six station standard gases with a concentration range of $340-450 \mathrm{ppm}$. These standard gases are produced by Deuste Steininger (Mühlhausen, Germany) in a gas matrix of so-called natural air (mixture of nitrogen, oxygen and argon) and filled in $10 \mathrm{~L}$ aluminium cylinders (Luxfer). At Trainou station, we use two-stage nickel-plated brass pressure regulators (Model 14, Scott Speciality Gases, Breda, The Netherlands). The station standard gases have been calibrated against the WMO X2007 scale (Zhao and Tans, 2006) at the LSCE using the Loflo 2-D analyser in 2006 and 2011. The difference between the calibrations in 2006 and 2011 was for all six cylinders smaller than $0.03 \mathrm{ppm}$. Therefore we used the arithmetic mean of both calibrations. For each calibration sequence, we repeat a pyramid-like pattern eight times, injecting the calibration gases and the reference gas in ascending and descending order of concentrations; each standard gas analysis lasts $10 \mathrm{~min}$. For the following calculations, a mean of the last $4 \mathrm{~min}$ of analysis is taken. To determine and correct the instrument drift, the reference gas is injected for $10 \mathrm{~min}$ in the sample cell once per hour. After drift correction using the hourly reference gas analysis, the calibration results showed that the residual drift is lower than $1 \mathrm{ppb}$ per day, which allows the calibrations of the instrument to be done no more frequently than once every eight days to maintain precision at $0.01 \mathrm{ppm}$.

Between two full-span calibrations, the ambient air measurement cycle, which lasts $7 \mathrm{~h}$, is repeated 24 times. The ambient air measurement cycle is a sequence composed of five $10 \mathrm{~min}$ passages of the air from 180,100, 50, 180 and $50 \mathrm{~m}$ levels bracketed by $10 \mathrm{~min}$ reference gas analysis (one every hour). Every $23 \mathrm{~h}$, these ambient air measurements are replaced by a so-called target gas for quality control for $50 \mathrm{~min}$. All data processing applied to the air measurements is also applied to the target gas measurements, in order to monitor the instrument performance and long-term stability. The upper panel of Fig. 5 shows the time series of target gas for the CARIBOU. We found a mean $\mathrm{CO}_{2}$ standard deviation of $0.06 \mathrm{ppm}$. Part of this variation is caused by flushing problems of the pressure regulator. At the beginning of the measurements, the flushing period was only 10-20 min, which was not adapted for the target flow $\left(20 \mathrm{~mL} \mathrm{~min}^{-1}\right)$ and the quality of the pressure regulators. The increase of the flushing period at the end of 2008 to $50 \mathrm{~min}$ led to smaller variations of the target gas.

\subsection{GC measurement system for analysis of atmospheric $\mathrm{CO}_{2}, \mathrm{CH}_{4}, \mathrm{~N}_{2} \mathrm{O}, \mathrm{SF}_{6}, \mathrm{CO}$ and $\mathrm{H}_{2}$}

The GC measurement system is based on a commercial gas chromatography (GC), 6890N from Agilent Technologies, which was modified in our laboratory (Messager, 2007). The modifications were done in accordance with a workshop on the harmonization of measurement techniques as part of the framework of the CHIOTTO project and of the existing GC system in our central laboratory in Gif-sur-Yvette. After optimization, the GC-system was installed at Trainou station in July 2006. Our GC system is equipped with a flame ionization detector (FID) in order to detect $\mathrm{CH}_{4}$ and $\mathrm{CO}_{2}$ (via nickel catalyst) and an electron capture detector $(\mu \mathrm{ECD})$ for $\mathrm{N}_{2} \mathrm{O}$ and SF6 (Lopez et al., 2012). In October 2008, we coupled a second GC containing a reduction gas detector (PP1 analyser, Peak Laboratories) to the existing GC system to analyse simultaneously $\mathrm{CO}$ and $\mathrm{H}_{2}$ (Yver et al., 2011).

Figure 4 shows a schematic of the gas flow though the GC system. The principal parameters are summarized in Table 2. A 16 position valve (Valco Vici, UWE, microelectronic actuator) \#7 is used to switch between the four air inlets (180, 100,50 and $5 \mathrm{~m}$ height), standard and target gases. The sample loops are flushed with dry ambient air or standard gas with a flow rate of $200 \mathrm{~mL} \mathrm{~min}^{-1}$, controlled by the EPC (electronic pressure control, AUX 5). After $45 \mathrm{~s}$, EPC AUX 5 is closed, allowing a pressure and temperature equilibration for $30 \mathrm{~s}$. The three sample valves (\#1a, \#1b and \#5) are then switched simultaneously in order to transfer the content of the sample loops to the separation columns. All valves are installed in a closed electrical rack system, to protect against short-term temperature variations.

For the $\mathrm{CO}_{2} / \mathrm{CH}_{4}$ branch, nitrogen $(5.0,99.999 \%)$ is used as carrier gas for the separation on a packed Hayesep Q column. At a flow rate of $50 \mathrm{~mL} \mathrm{~min}^{-1}$ (EPC AUX 3), $\mathrm{CH}_{4}$ elutes about $70 \mathrm{~s}$ after injection and $\mathrm{CO}_{2} 120 \mathrm{~s}$ after injection. After the $\mathrm{CH}_{4}$ peak is detected on the FID, valve \#4 is switched from the bypass to the nickel catalyst at $390^{\circ} \mathrm{C}$, which converts $\mathrm{CO}_{2}$ to $\mathrm{CH}_{4}$ permitting the $\mathrm{CO}_{2}$ analysis on the FID. The efficiency of the $\mathrm{Ni}$ catalyst for reduction of $\mathrm{CO}_{2}$ to $\mathrm{CH}_{4}$ is better than $96 \%$. To supply hydrogen to the FID and the Ni catalyst, we used hydrogen generators from Parker/Balston (model A9150 until summer 2008 and after model 9200). In 2010, we replaced the hydrogen generator again with a NM- $\mathrm{H}_{2} 250$ (FDBS). Synthetic air is supplied by a combination of a compressor (Jun Air) and a purifier (Parker, Chromgas 1000).

For the $\mathrm{N}_{2} \mathrm{O} / \mathrm{SF}_{6}$ branch, a $5 \% \mathrm{CH}_{4}$ in Argon (ECD quality) is used as carrier gas. The separation of the peaks is performed on two packed Hayesep columns. At $70 \mathrm{~s}$ after 
Table 2. Settings of the GC parameters.

\begin{tabular}{|c|c|c|c|}
\hline & $\mathrm{CO}_{2}$ and $\mathrm{CH}_{4}$ & $\mathrm{~N}_{2} \mathrm{O}$ and $\mathrm{SF}_{6}$ & $\mathrm{CO}$ and $\mathrm{H}_{2}$ \\
\hline Oven temperature (column) & $80^{\circ} \mathrm{C}$ & $80^{\circ} \mathrm{C}$ & $106^{\circ} \mathrm{C}$ \\
\hline Sample loops & $15 \mathrm{~mL}$ & $10 \mathrm{~mL}$ & $1 \mathrm{~mL}$ \\
\hline Flow through sample loops & $200 \mathrm{~mL} \mathrm{~min}^{-1}$ & $200 \mathrm{~mL} \mathrm{~min}^{-1}$ & $200 \mathrm{~mL} \mathrm{~min}^{-1}$ \\
\hline Carrier gas & Nitrogen 5.0 & $\mathrm{Ar} / \mathrm{CH} 4(5 \%)$ ECD quality & Synthetic air \\
\hline Carrier gas (flow) & $50 \mathrm{~mL} \mathrm{~min}^{-1}$ & $\begin{array}{l}40 \mathrm{~mL} \min ^{-1} \\
\text { (backflush: } 55 \mathrm{~mL} \mathrm{~min}^{-1} \text { ) }\end{array}$ & $15 \mathrm{~mL} \mathrm{~min}^{-1}$ \\
\hline Analytical columns & $\begin{array}{l}\text { Hayesep-Q, 80-100 mesh } \\
(3.65 \mathrm{~m} \times 4.7625 \mathrm{~mm})\end{array}$ & $\begin{array}{l}\text { Hayesep-Q, } 80-100 \mathrm{mesh} \\
(1.829 \mathrm{~m} \times 4.7625 \mathrm{~mm})\end{array}$ & $\begin{array}{l}\text { Molecular Sieve } 5 \AA \text { } 60-80 \text { mesh } \\
(2.032 \mathrm{~m} \times 3.175 \mathrm{~mm})\end{array}$ \\
\hline Pre-column & & $\begin{array}{l}\text { Hayesep-Q, 80-100 mesh } \\
(1.219 \mathrm{~m} \times 4.7625 \mathrm{~mm})\end{array}$ & $\begin{array}{l}\text { Unibeads } 1 \mathrm{~S} \text { column } 60-80 \text { mesh } \\
(0.762 \mathrm{~m} \times 3.175 \mathrm{~mm})\end{array}$ \\
\hline Detector & FID & $\mu \mathrm{ECD}$ & RGD \\
\hline \multirow[t]{4}{*}{ Detector temperature } & $300^{\circ} \mathrm{C}$ & $395^{\circ} \mathrm{C}$ & $265^{\circ} \mathrm{C}$ \\
\hline & $\mathrm{H}_{2}$ Flow: $50 \mathrm{~mL} \mathrm{~min}^{-1}$ & & \\
\hline & Air Flow: $400 \mathrm{~mL} \mathrm{~min}-1$ & & \\
\hline & Methanizer: $390^{\circ} \mathrm{C}$ & & \\
\hline
\end{tabular}

injection, when $\mathrm{N}_{2} \mathrm{O}$ and $\mathrm{SF}_{6}$ are on the analytical column, the pre-column is back flushed by turning valve \#3. This prevents compounds with longer retention times from eluting with the next injection and therefore shortens the analysis time. $\mathrm{N}_{2} \mathrm{O}$ and $\mathrm{SF}_{6}$ are detected on the ECD 150 and $180 \mathrm{~s}$ respectively, after injections.

Electron capture detectors are known for their non-linear responses when measuring $\mathrm{N}_{2} \mathrm{O}$ and the possible problem of co-elution of $\mathrm{N}_{2} \mathrm{O}$ and $\mathrm{CO}_{2}$, depending on the column setup. As described in more detail by Lopez et al. (2012) and Schmidt et al. (2001), we determine the non-linear response of the ECD using a reference sample diluted with $\mathrm{N}_{2} \mathrm{O}$-free and $\mathrm{CH}_{4}$-free air. Methane is used to determine the dilution factor, as the response of the FID for $\mathrm{CH}_{4}$ is linear within the chosen range. We found that the $\mu \mathrm{ECD}$ at Trainou underestimates the $\mathrm{N}_{2} \mathrm{O}$ concentration with increasing values, but a linear correction can be added to describe the response of the ECD in the range of 300 to $350 \mathrm{ppb}$ (Messager, 2007; Lopez et al., 2012). The slope of the correction function is 0.07 for the $\mathrm{N}_{2} \mathrm{O}$ measurements at Trainou station. A two-point calibration strategy with one working standard of $315 \mathrm{ppb}$ and a second one of $340 \mathrm{ppb} \mathrm{N}_{2} \mathrm{O}$ was therefore chosen in order to correct for the non-linear behaviour of the $\mu \mathrm{ECD}$ (see Sect. 3.3.2)

We have tested the co-elution of $\mathrm{N}_{2} \mathrm{O}$ and $\mathrm{CO}_{2}$ using a small amount of Ascarite (Fluka, \#11133, 5-20 mesh), followed by a magnesium perchlorate $\left[\mathrm{Mg}\left(\mathrm{ClO}_{4}\right)_{2}\right]$ drying which removes $\mathrm{CO}_{2}$ from a reference sample. As described by Lopez et al. (2012), the influence of the $\mathrm{CO}_{2}$ co-elution is negligible for the $\mathrm{N}_{2} \mathrm{O}$ measurements at Trainou. They also reported a cross sensitivity of $\mathrm{N}_{2} \mathrm{O}$ and $\mathrm{SF}_{6}$, at Gif-sur-Yvette station, when $\mathrm{SF}_{6}$ peaks exceeded $15 \mathrm{ppt}$. At Trainou station we never observed $\mathrm{SF}_{6}$ mole fractions larger than $14 \mathrm{ppt}$, but we were careful not to use calibration gases with elevated $\mathrm{SF}_{6}$.
In order to add $\mathrm{CO}$ and $\mathrm{H}_{2}$ measurements, we coupled a reduction gas detector (RGD) from Peak Performer, to the Agilent GC in 2008 (Yver et al., 2011). The sample loop of the RGD is connected in series with the sample loop of the FID and ECD. The analysis is performed by reduction of mercuric oxide and detection of mercury vapour by UV absorption. Synthetic air (Air Liquide, high purity) purified by an additional filter in the chromatograph is used as carrier gas. Aliquots of air are flushed through a $1 \mathrm{~mL}$ sampling loop. After equilibration, the sample is injected onto the columns. The pre-column (Unibeads 1S) is used to separate $\mathrm{H}_{2}$ and $\mathrm{CO}$ from other components and the analytical one (Molecular Sieve $5 \AA$ ) effectively separates $\mathrm{H}_{2}$ and $\mathrm{CO}$ before being analysed by the mercury detector. The oven temperature is held at $105^{\circ} \mathrm{C}$ and the catalytic chamber is heated to $265^{\circ} \mathrm{C}$.

The non-linearity of the RGD detector is regularly determined using a set of cylinders spanning $\mathrm{H}_{2}$ mole fractions between 213 and $996 \mathrm{ppb}$ and $\mathrm{CO}$ mole fractions between 157 and $523 \mathrm{ppb}$. The standard cylinders for $\mathrm{H}_{2}$ were calibrated at the Max Planck Institute (MPI) Jena and for CO by NOAA/CMSL. During the test of the analyser in our laboratory, we performed a non-linearity test with 11 standard cylinders for $\mathrm{H}_{2}$ and 5 for CO. During operation at Trainou station the number of standard cylinders had to be reduced to only four for both species due to logistical problems. In general, the standard cylinders are evaluated every 6-12 months. Over the described measurement period, the non-linearity of the RGD at Trainou did not change significantly for $\mathrm{CO}$ and $\mathrm{H}_{2}$ in the range of observed mixing ratios. However, for $\mathrm{H}_{2}$, a shift in the non-linearity was observed for mole fractions above $800 \mathrm{ppb}$. As the ambient air mole fractions are below $650 \mathrm{ppb}$, all data are corrected with the same third degree polynomial fit. Only the quality control gas (Target) with a $\mathrm{H}_{2}$ mole fraction above $800 \mathrm{ppb}$ is affected by this choice with an observed shift over time (see Sect. 3.3.2). 


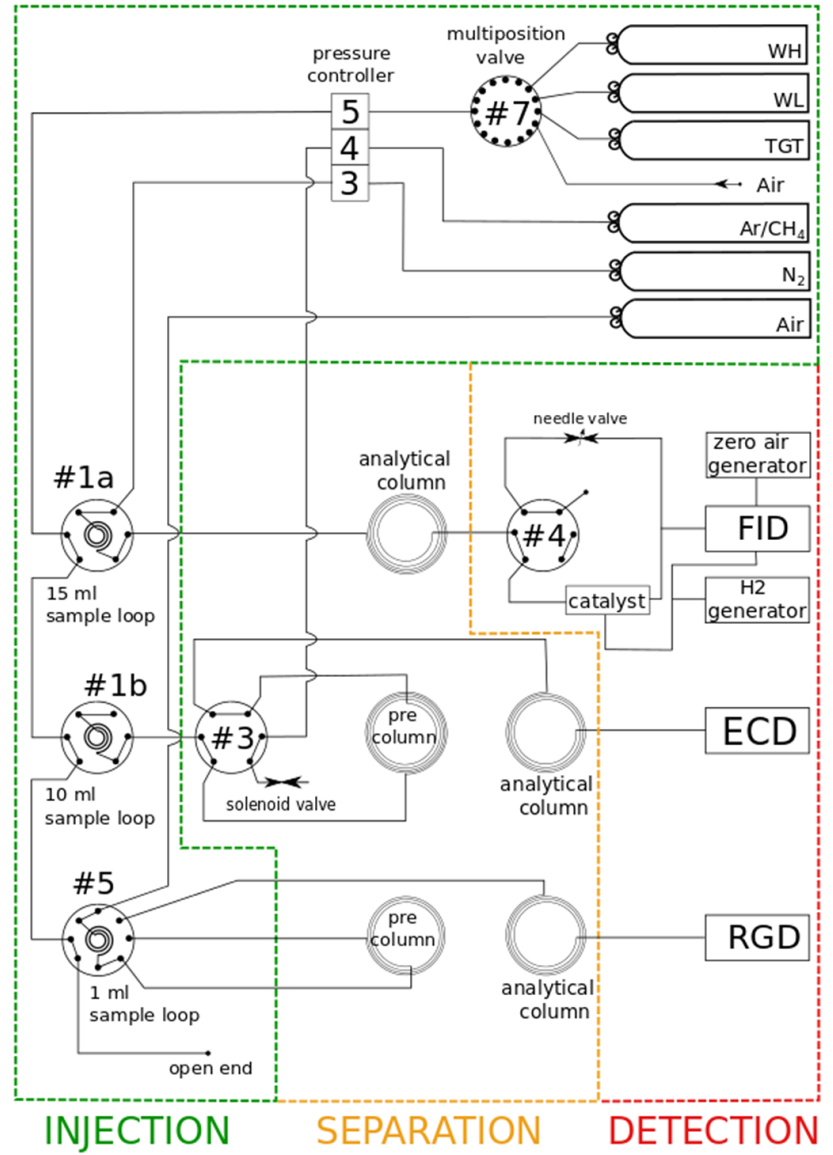

Figure 4. Schematic of the two coupled GC systems. The FID and the ECD detector are housed in a GC 6890N from Agilent Technologies and the reduction gas detector (RGD) in a PP1 from Peak Laboratories. The three sample loops are flushed with the same sample and injected at the same time.

With this setup, we are able to achieve injection and detection of one sample within $5 \mathrm{~min}$, allowing 12 ambient air or standard gas injections over $1 \mathrm{~h}$.

\subsubsection{Data acquisition and remote controlling}

For the full control of the GC system, data acquisition and remote controlling, we use one $\mathrm{PC}$, which is equipped with the chromatography software CHEMSTATION (A.09.03) from Agilent. To treat the signal of the PP1 GC in the same way and to synchronize the two GCs, we added an analog-todigital converter (Agilent Technologies Inc 35900E). The CHEMSTATION software allows for scheduling the switching of all valves in order to control the temperature of the oven and the detectors and to regulate the flow of the carrier gases and the flushing of the sample loops. The detector signals of both GCs are recorded by the CHEMSTATION and at the end of each injection method, the integration of the peaks is performed.
Once a day, we automatically transfer the raw data (chromatograms and integrated peak areas and heights) via file transfer protocol to a central computer at LSCE. From there, peak areas and heights, sample information, etc., are read by the database and computed to concentration values. Chromatograms and other additional information are stored separately in the case of necessary data re-evaluation. In case modifications to the methods, sequences or integrations are needed, we can remotely access the CHEMSTATION at Trainou tower from our institute at any time.

\subsubsection{Calibration and quality control}

To correct for possible drift of the measurement system, we decided to perform the working standard analysis every $30 \mathrm{~min}$. As the ECD and also the RGD show a non-linear behaviour, we inject a working standard low (WL) and a working standard high (WH) in order to apply a two-point calibration. These standards are produced by Deuste Steininger (Mühlhausen, Germany), and filled in $40 \mathrm{~L}$ aluminium cylinders (Luxfer). The concentration range is chosen to bracket the atmospheric concentration range for all analysed gases at Trainou station. As the first working standards did not contain $\mathrm{H}_{2}$, a working standard "special" (WS) is used to calculate the $\mathrm{H}_{2}$ concentration. The non-linearity of the RGD is corrected using a third-degree polynomial fit. This fit is determined by measuring a range of four standard gases (Yver et al., 2011).

Like for $\mathrm{CO}_{2}$ CARIBOU measurements, a target gas, with a known concentration value in between the $\mathrm{WL}$ and $\mathrm{WH}$ concentration, is analysed every $1-2 \mathrm{~h}$. A typical $1 \mathrm{~h}$ sequence consist of WH, WL, WS, Target, TR3, TR2, TR1, WH, WL, WS, TR3, TR2, TR1 and TR0. With this frequency of calibration, the theoretical lifetime of working standards is $1.5-2$ years and for the target gas 3-4 years.

The target gas is used to calculate the short-term repeatability (on a daily basis) and the long-term reproducibility. Figure 5 shows the time series of the hourly target gas injection for $\mathrm{CO}_{2}, \mathrm{CH}_{4}, \mathrm{~N}_{2} \mathrm{O}, \mathrm{SF}_{6}$ and since July 2009 , also for $\mathrm{CO}$ and $\mathrm{H}_{2}$. The large gaps in winter 2006/2007 are due to electrical power supply problems. We then had to stop all measurement systems between October 2006 and February 2007. In November 2007, the ECD was broken, and could only be replaced in August 2008. For the whole period of analysis, we found a mean standard deviation of the hourly target gas injection of $0.14 \mathrm{ppm}$ for $\mathrm{CO}_{2}, 3.2 \mathrm{ppb}$ for $\mathrm{CH}_{4}$, $0.7 \mathrm{ppb}$ for $\mathrm{N}_{2} \mathrm{O}, 0.08$ for $\mathrm{SF}_{6}, 1.9 \mathrm{ppb}$ for $\mathrm{CO}$ and $13 \mathrm{ppb}$ for $\mathrm{H}_{2}$. We can identify several periods where the GC was not working very well for different trace gas analyses, increasing the standard deviation of our target measurements. In 2009, we had repeated problems with hydrogen generators, which were not producing hydrogen that was sufficiently dry. After the replacement of the hydrogen generator in 2010, we achieved a $\mathrm{CH}_{4}$ repeatability of $1.4 \mathrm{ppb}$. Similar problems, as mentioned above but caused by the ECD, are reported 


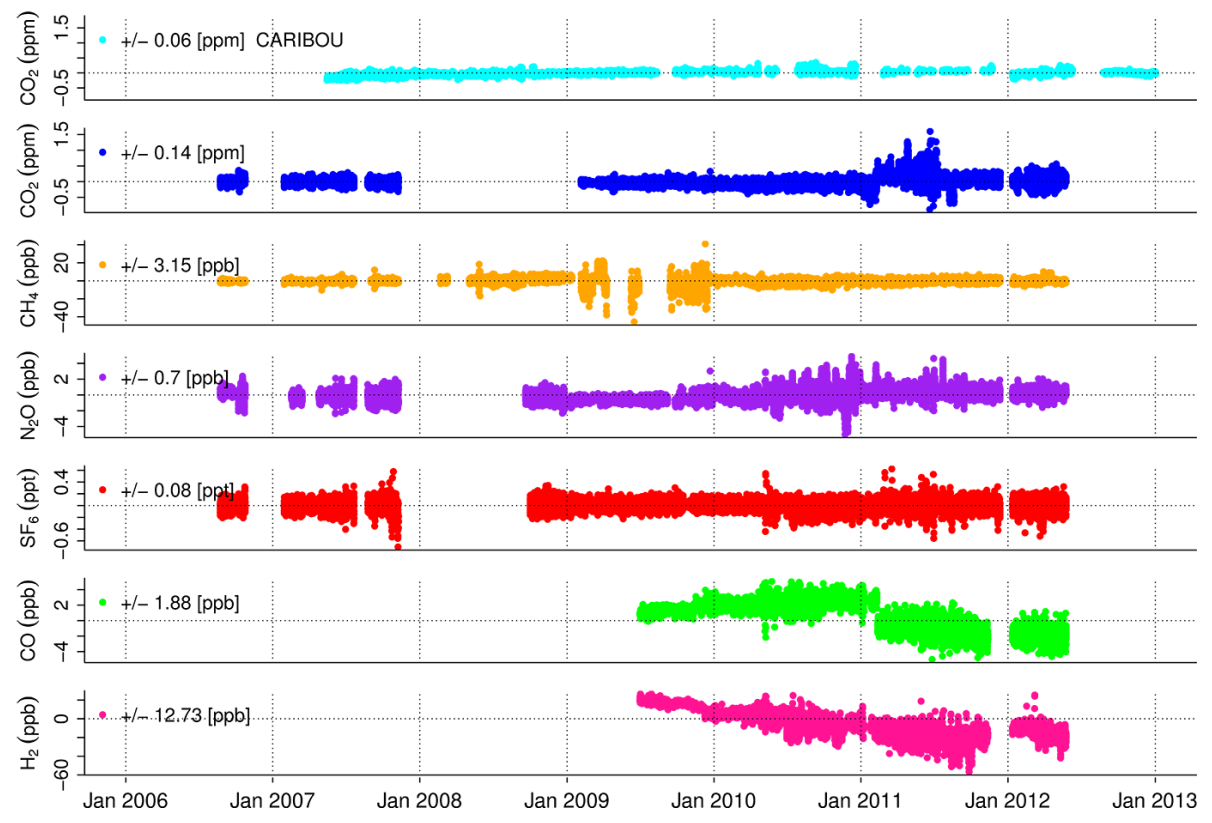

Figure 5. Long-term reproducibility of the target gases for $\mathrm{CO}_{2}$ measured with the CARIBOU and for $\mathrm{CO}_{2}, \mathrm{CH}_{4}, \mathrm{~N}_{2} \mathrm{O}, \mathrm{SF}_{6}, \mathrm{CO}_{\text {and }} \mathrm{H}_{2}$ measured with the coupled GC system. For all species the differences between measured data and their mean values are plotted against time. The drift of the target cylinder for $\mathrm{H}_{2}$ can be explained by the elevated mole fraction of $841 \mathrm{ppb}$ which is greatly above the typical high ambient air values of $650 \mathrm{ppb}$ at Trainou. With our non-linearity test we were not able to correct such high values.

for the $\mathrm{N}_{2} \mathrm{O}$ reproducibility. In 2009, the ECD worked without issues and the target gas showed a standard deviation of only $0.21 \mathrm{ppb}$. The hydrogen mole fraction of the target cylinder shows clearly a drift-like behaviour with decreasing values. As explained in Sect. 3.3, the non-linearity of the RGD-system changes for $\mathrm{H}_{2}$ mole fraction above $800 \mathrm{ppb}$. The target cylinder has a $\mathrm{H}_{2}$ concentration of $841 \mathrm{ppb}$ which is much above typical high ambient air values of $650 \mathrm{ppb}$ at Trainou. With our non-linearity test we were not able to correct such high values. Outside of the calibrated range has this target cylinder only a limited suitability for hydrogen and should be interpreted with care. To link the station to the international calibration scales, the working standards have been initially calibrated against gas tanks calibrated by the WMO calibration centres at NOAA (Zhao and Tans, 2006; Dlugokencky et al., 2005; Hall et al., 2007) or MPI Jena (Jordan and Steinberg, 2011). Before the end of the lifetime and in the case of drifts or jumps in the quality control gas, the working standards at the station are reanalysed in our laboratory in Gif-sur-Yvette. Details of the instrumentation used to calibrate our station standards in our laboratory and the WMO scales for different gases are summarized in Table 3 .

\subsection{Other instrumentation}

\subsubsection{Meteorological sensors}

Meteorological sensors are installed at the $180 \mathrm{~m}$ (TR3) and at the surface level on the top of the container about $5 \mathrm{~m}$ above ground (TR0). To measure the wind speed and direction, we use a sensor from Young (Model 05103L) and for the temperature and humidity a sensor from Vaisala (HUMICAP HMP45A). The data acquisition and transfer to the database is run by the CARIBOU software (see Sect. 3.2).

\subsubsection{Flask sampling}

Weekly flask sampling is performed from an independent sampling line at the $180 \mathrm{~m}$ level with a standard flask sampler used in the French GHG network. The sampling unit consist of a diaphragm pump (Model N86 KNDC, KNF Neuberger) which draws air through a chemical drying cartridge filled with anhydrous magnesium perchlorate $\left[\mathrm{Mg}\left(\mathrm{ClO}_{4}\right)_{2}\right]$. Air is collected in $1 \mathrm{~L}$ glass flasks sealed with PTFE (polytetrafluoroethene) O-rings (Normag Labor- und Prozesstechnik, Ilmenau, Germany). Flasks are collected in pairs and pressurized to 2 bar absolute pressure. The sampling started with a low frequency in 2006. Since June 2007, a regular sampling has been performed during the weekly maintenance of the station. The flasks are transported to our central lab at Gif-sur-Yvette and analysed for mixing ratios of $\mathrm{CO}_{2}, \mathrm{CH}_{4}$, $\mathrm{N}_{2} \mathrm{O}, \mathrm{SF}_{6}, \mathrm{H}_{2}$, and $\mathrm{CO}$ by GC. The isotopic composition of $\mathrm{CO}_{2}$ is determined using a Finnigan MAT252 isotope ratio mass spectrometer (IRMS), equipped with a trapping box for cryogenic separation of $\mathrm{CO}_{2}$ from air. 
Table 3. Primary calibration scales at the LSCE central lab, which are used to calibrate the station standards. $\mathrm{CO}_{2}$ calibration of the working standards is generally performed with the Loflo (NDIR) analyser. The other gases are calibrated by GC system.

\begin{tabular}{lllll}
\hline Component & Instrument & Range & \# of tanks & Scale \\
\hline $\mathrm{CO}_{2}$ & Loflo & $318-468 \mathrm{ppm}$ & 7 & WMO X 2007 \\
$\mathrm{CO}_{2}$ & GC (LSCE) & $365-462 \mathrm{ppm}$ & 6 & WMO X 2007 \\
$\mathrm{CH}_{4}$ & GC (LSCE) & $1634-2081 \mathrm{ppb}$ & 6 & NOAA04 scale \\
$\mathrm{N}_{2} \mathrm{O}$ & GC (LSCE) & $302-340 \mathrm{ppb}$ & 6 & NOAA 2006A \\
$\mathrm{SF}_{6}$ & GC (LSCE) & $6-15 \mathrm{ppb}$ & 6 & NOAA 2006 \\
$\mathrm{CO}$ & GC (LSCE) & $41-595 \mathrm{ppb}$ & 6 & NOAA-GMD/WMO 2004 \\
$\mathrm{H}_{2}$ & GC (LSCE) & $430-810 \mathrm{ppb}$ & 3 & MPI 2009 \\
\hline
\end{tabular}

\subsubsection{Radon-222 measurements}

In June 2009, we installed a radon measurement instrument at Trainou, which was tested between January 2007 and May 2009 in Gif-sur-Yvette (Yver et al., 2009). The detection method based on a double filter was installed in cooperation with the Australian Nuclear Science and Technology Organisation (ANSTO). In the double filter method (Whittlestone and Zahorowski, 1998; Zahorowski et al., 2004), ambient air is continuously pumped through two $200 \mathrm{~L}$ cylinders and through a first filter to the analysis chamber. During this first step, radon-222 $\left({ }^{222} \mathrm{Rn}\right)$ disintegrates as the time residence is ten times higher than its half-life and the filter retains all solid particles letting just ${ }^{222} \mathrm{Rn}$ coming in the analysis chamber. In this chamber, ${ }^{222} \mathrm{Rn}$ daughters are produced and collected on a second filter. The $\alpha$-decay of these daughter elements is then counted. The instrument is regularly calibrated with known quantity of ${ }^{222} \mathrm{Rn}$ emitted by a ${ }^{226}$ Ra source (type $2000 \mathrm{~A}-20$, Pylon). The inlet line is installed at the $180 \mathrm{~m}$ level.

\subsection{Comparison of the different instruments and flask analysis}

In 2007 and from 2009 to 2012, the GC system and the CARIBOU analysed $\mathrm{CO}_{2}$ mole fractions at the 50, 100 and $180 \mathrm{~m}$ sampling level. The sampling of the different levels for both analysers is not synchronized, but both analysers sample each level between one and two times per hour. In the case of the GC, it is a single injection and in the case of the CARIBOU a $10 \mathrm{~min}$ interval with a frequency of $1 \mathrm{~Hz}$. In order to compare both values, we used the $1 \mathrm{~h}$ mean values, which risks a maximum time shift of $50 \mathrm{~min}$ in the case of only one injection per analyser during the $1 \mathrm{~h}$ with a maximum time difference. The mean differences and the $1 \sigma$ standard deviations are summarized in Table 4 for the different years and the different sampling level. The values correspond to the GC measurement minus CARIBOU measurement. Generally, the $\mathrm{CO}_{2}$ difference between both analysers was of the order of $0.1 \mathrm{ppm}$ or less, with the exception of the years 2007 and 2011, when the GC measured around $0.15 \mathrm{ppm}$ higher values at all three sampling level. This indicates a possible leakages or a calibration problem of the GC, but afterwards we were not able to isolate it to one specific analyser.

In parallel to the GC measurements, weekly flask sampling at the $180 \mathrm{~m}$ level was carried out and analysed on the GC system in the LSCE central lab in Gif-surYvette (see Sect. 3.4.2). During the period 2007-2012 we monitored a mean difference between GC Trainou and flasks of $-0.08 \pm 1.40 \mathrm{ppm} \mathrm{CO} \mathrm{CO}_{2},-0.7 \pm 7.3 \mathrm{ppb} \mathrm{CH}_{4}$ $-0.64 \pm 0.62 \mathrm{ppb} \mathrm{N} \mathrm{N}_{2} \mathrm{O}, 0.01 \pm 0.10 \mathrm{ppb} \mathrm{\textrm {SF } _ { 6 }}, 1.5 \pm 5.3 \mathrm{ppb}$ $\mathrm{CO}$ and $4.85 \pm 6.9 \mathrm{ppb} \mathrm{H}_{2}$.

\subsection{Additional instrumentation}

In cooperation with the Institut für Umweltphysik (IUP) at the University of Heidelberg, we installed a sampler for ${ }^{14} \mathrm{CO}_{2}$ sampling. Integrated atmospheric ${ }^{14} \mathrm{CO}_{2}$ samples have been collected from the $180 \mathrm{~m}$ inlet line over a two week period in $\mathrm{CO}_{2-}$ free sodium hydroxide solution since January 2008. The flushing rate is adjusted in order to sample $\mathrm{CO}_{2}$ from a total volume of $20-25 \mathrm{~m}^{3}$ of air. The sampling and analysis technique is described in detail by Levin et al. (1980).

Since December 2010, a vertically pointed aerosol lidar system (ALS300, Leosphere, Orsay, France) for monitoring atmospheric boundary layer (ABL) depths is routinely operated at Trainou tower. Full details of the instrumentation and the first time series of ABL depths can be found in Pal et al. $(2012,2014)$.

\section{Measurement of ambient air}

Figure 6 shows the hourly averaged time series of $\mathrm{CO}_{2}, \mathrm{CH}_{4}$, $\mathrm{N}_{2} \mathrm{O}$ and $\mathrm{SF}_{6}, \mathrm{CO}, \mathrm{H}_{2}$ mole fractions and ${ }^{222} \mathrm{Rn}$ activity for the four sampling heights $(180 \mathrm{~m}$ in blue, $100 \mathrm{~m}$ in green, $50 \mathrm{~m}$ in red and $5 \mathrm{~m}$ in black). The lowest sampling level $(5 \mathrm{~m})$ was only added in October 2010 . As already described in Sect. 3.3.2, all measurement systems were stopped between October 2006 and February 2007. In November 2007, the ECD was broken, and could only be replaced in August 2008 leading to gaps in the time series of $\mathrm{N}_{2} \mathrm{O}$ and $\mathrm{SF}_{6}$. 
Table 4. Mean annual $\mathrm{CO}_{2}$ difference and $1 \sigma$ standard deviation for the three ambient air sampling lines at Trainou station (GC-CARIBOU). For the mean difference of the period 2007-2012 we applied a 2 sigma filter.

\begin{tabular}{llll}
\hline Year & $\begin{array}{l}50 \mathrm{~m} \text { sampling level } \\
\Delta \mathrm{CO}_{2}(\mathrm{ppm})\end{array}$ & $\begin{array}{l}100 \mathrm{~m} \text { sampling level } \\
\Delta \mathrm{CO}_{2}(\mathrm{ppm})\end{array}$ & $\begin{array}{l}180 \mathrm{~m} \text { sampling level } \\
\Delta \mathrm{CO}_{2}(\mathrm{ppm})\end{array}$ \\
\hline 2007 & $0.12 \pm 1.75$ & $0.12 \pm 1.0$ & $0.15 \pm 0.75$ \\
2009 & $0.11 \pm 1.3$ & $0.05 \pm 1.01$ & $-0.06 \pm 1.0$ \\
2010 & $0.07 \pm 1.05$ & $0.03 \pm 1.09$ & $-0.02 \pm 0.88$ \\
2011 & $0.13 \pm 0.82$ & $0.18 \pm 1.1$ & $0.21 \pm 1.1$ \\
2012 & $-0.01 \pm 1.26$ & $0.07 \pm 0.97$ & $-0.07 \pm 0.81$ \\
\hline $2007-2012$ & $0.08 \pm 1.00$ & $0.09 \pm 1.05$ & $0.01 \pm 0.93$ \\
\hline
\end{tabular}

\subsection{Growth rates and seasonal variations}

We determine the growth rate and the seasonal cycles for all trace gases at the highest sampling level at $180 \mathrm{~m}$. We employ the curve fitting procedure described by Thoning et al. (1989) and Masarie and Tans (1995) to the daily mean values. The curve fit incorporates harmonic and quadratic functions, and an 80-day smoothing is applied to the residuals. A $3 \sigma$ filter is applied in the smoothing process to obtain the best fit curve, excluding statistical outliers.

The $\mathrm{CO}_{2}$ time series shows a seasonal cycle with minimum value in summertime (August) and a wintertime maximum (January) as expected. Superimposed on this cycle are synoptic and diurnal peaks generally associated with regional pollution events and changes in the boundary layer height. Diurnal variations with $\mathrm{CO}_{2}$ mole fractions of up to $550 \mathrm{ppm}$ during summer have been monitored at the lowest sampling level, $5 \mathrm{~m}$ above ground, whereas at the $180 \mathrm{~m}$ level, elevated mole fractions of up to $450 \mathrm{ppm}$ occurs from time to time in winter. The amplitude of the diurnal variations decreases with the increasing sampling height. We computed a $\mathrm{CO}_{2}$ annual growth rate of $2.2 \mathrm{ppm}$ per year for the $180 \mathrm{~m}$ sampling level between 2007 and 2012, considering all-day round measurements.

The $\mathrm{CH}_{4}$ time series shows a mean seasonal cycle of approximately $70 \mathrm{ppb}$ peak-to-peak amplitude with higher values during January and lower values at the end of July. High short-term (diurnal) variations occur during winter correlated with pollution events of other trace gases, when the nocturnal planetary boundary layer height is low. During these events the $\mathrm{CH}_{4}$ mole fraction can increase to up to $2400 \mathrm{ppb}$ at the lowest $(5 \mathrm{~m})$ and $2050 \mathrm{ppb}$ at the $180 \mathrm{~m}$ sampling level. Averaged over the plotted measurement period, $\mathrm{CH}_{4}$ increased $4.1 \mathrm{ppb}$ per year at Trainou station (180 m sampling).

$\mathrm{N}_{2} \mathrm{O}$ mole fractions at $180 \mathrm{~m}$ sampling height increase with an average annual growth rate of $0.78 \mathrm{ppb}$ per year. Again the lower sampling levels show larger variability likely reflecting local emissions from soil and other sources. In the study of Lopez et al. (2012), $\mathrm{N}_{2} \mathrm{O}$ emissions in the catchment area of Trainou station are discussed in detail.
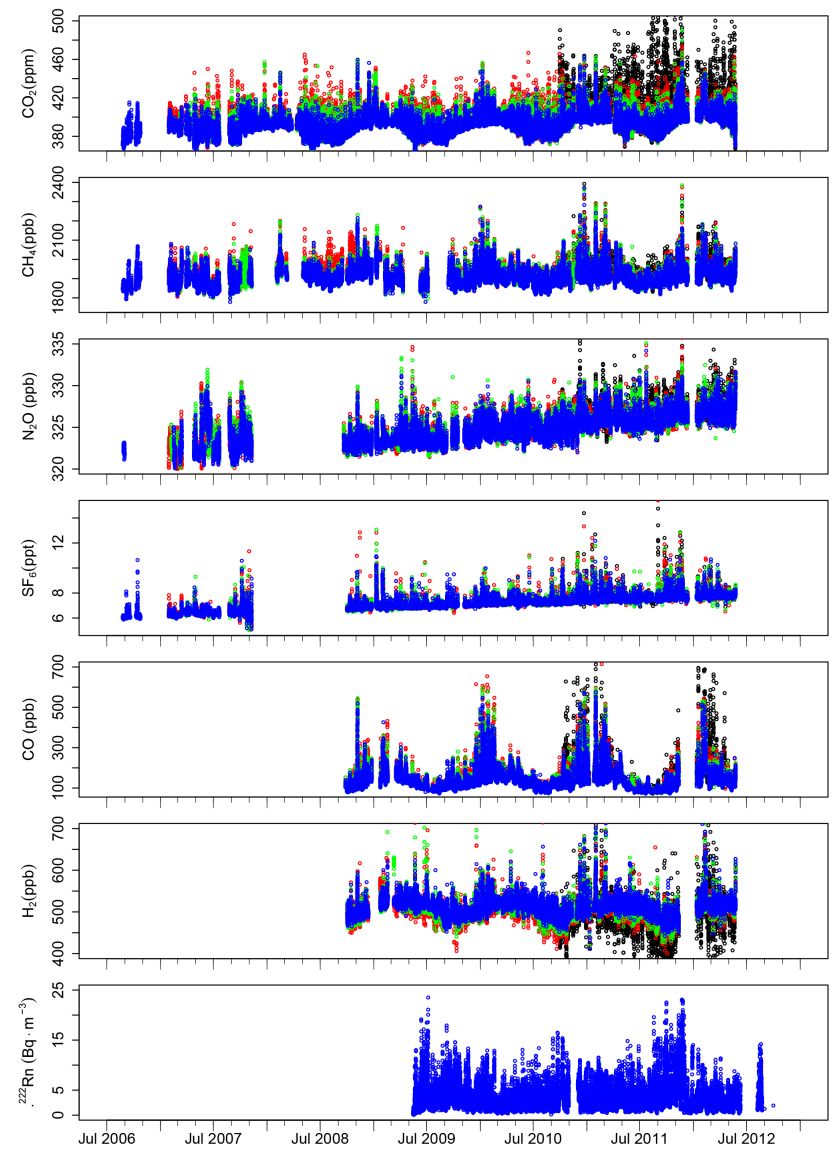

Figure 6. Time series of atmospheric $\mathrm{CO}_{2}, \mathrm{CH}_{4}, \mathrm{~N}_{2} \mathrm{O}, \mathrm{SF}_{6}, \mathrm{CO}$, $\mathrm{H}_{2}$ and ${ }^{222} \mathrm{Rn}$ measurements from the $180 \mathrm{~m}$ (blue), $100 \mathrm{~m}$ (green), $50 \mathrm{~m}$ (red) and $5 \mathrm{~m}$ (black) inlet line. From November 2007 to September 2008 the $\mathrm{N}_{2} \mathrm{O}$ and $\mathrm{SF}_{6}$ measurements were interrupted due to broken ECD. CO, $\mathrm{H}_{2}$ and ${ }^{222} \mathrm{Rn}$ analysers were installed in 2008 and 2009 at the station.

The $\mathrm{SF}_{6}$ increase rate at Trainou $180 \mathrm{~m}$ sampling level equals 0.29 ppt per year. Superimposed on this trend are a few events with elevated $\mathrm{SF}_{6}$ mole fractions of nearly $15 \mathrm{ppt}$ at lower sampling levels $(50 \mathrm{~m}$ and $5 \mathrm{~m})$ and approximately $10 \mathrm{ppt}$ at the highest sampling level. 

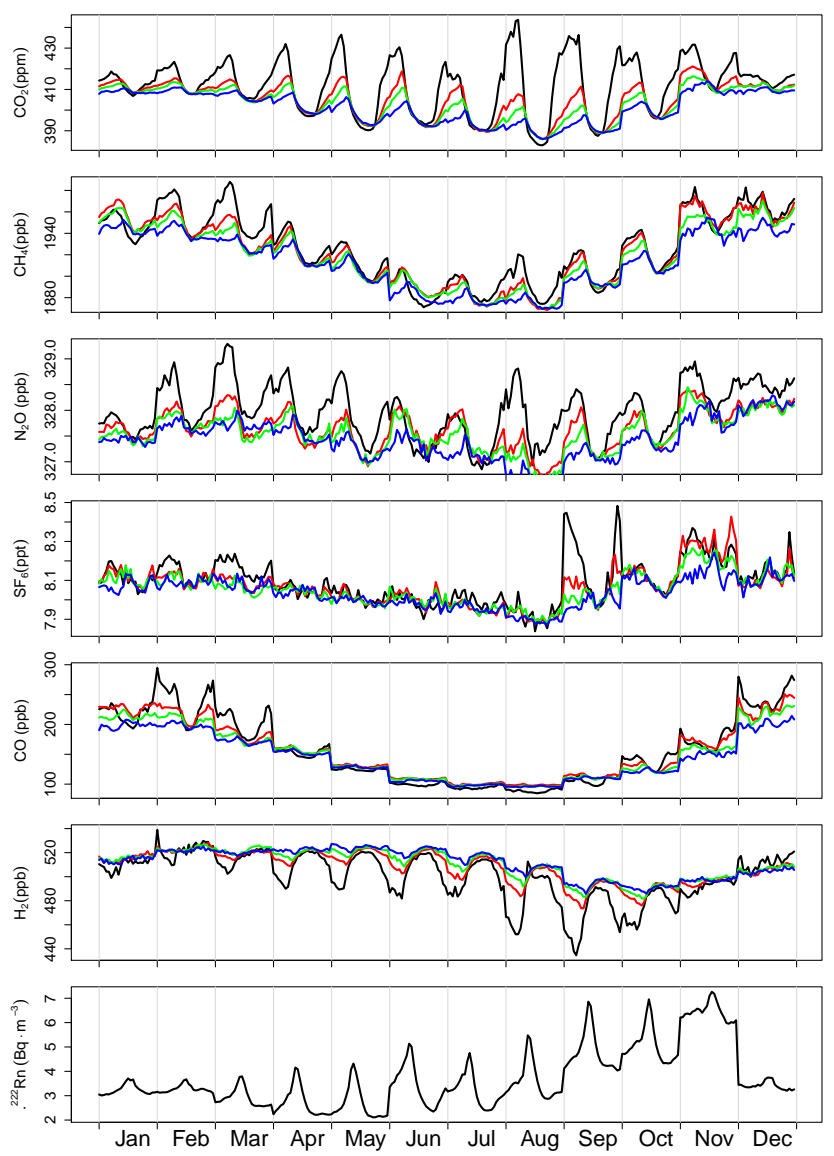

Figure 7. Mean diurnal cycles of $\mathrm{CO}_{2}, \mathrm{CH}_{4}, \mathrm{~N}_{2} \mathrm{O}, \mathrm{SF}_{6}, \mathrm{CO}, \mathrm{H}_{2}$ and ${ }^{222} \mathrm{Rn}$ for the sampling levels $5 \mathrm{~m}$ (black), $50 \mathrm{~m}$ (red) $100 \mathrm{~m}$ (green) and $180 \mathrm{~m}$ (blue).

Yver et al. (2011) have described the first year of CO and $\mathrm{H}_{2}$ time series. We confirmed their findings of seasonal cycles at Trainou station with minimum values for $\mathrm{CO}$ mole fractions in July and for $\mathrm{H}_{2}$ in September. Superimposed on this signal are diurnal peaks and synoptic peaks. In winter, $\mathrm{CO}$ mole fractions of up to $700 \mathrm{ppb}$ have been observed at the lowest sampling level, $5 \mathrm{~m}$ above ground, whereas at the $180 \mathrm{~m}$ level elevated mole fractions of up to approximately $500 \mathrm{ppb}$ occurs occasionally. In summer, $\mathrm{H}_{2}$ mole fractions can be smaller at the lower levels than at the $180 \mathrm{~m}$ level due to uptake of $\mathrm{H}_{2}$ by the soil.

\subsection{Mean diurnal variation and vertical gradient}

Figure 7 summarises the mean diurnal variation of $\mathrm{CO}_{2}$, $\mathrm{CH}_{4}, \mathrm{~N}_{2} \mathrm{O}, \mathrm{SF}_{6}, \mathrm{CO}$ and $\mathrm{H}_{2}$ mole fractions and ${ }^{222} \mathrm{Rn}$ activity for the four sampling levels averaged by month and hour of day. The $x$ axis of each month covers an interval between 00:00 and 24:00 (GMT), where midnight GMT corresponds to 01:00 local time at Trainou station. $\mathrm{CO}_{2}, \mathrm{CH}_{4}$ and $\mathrm{N}_{2} \mathrm{O}$ mole fractions show larger increases during nighttime, with strong accumulations at ground level. During afternoon,
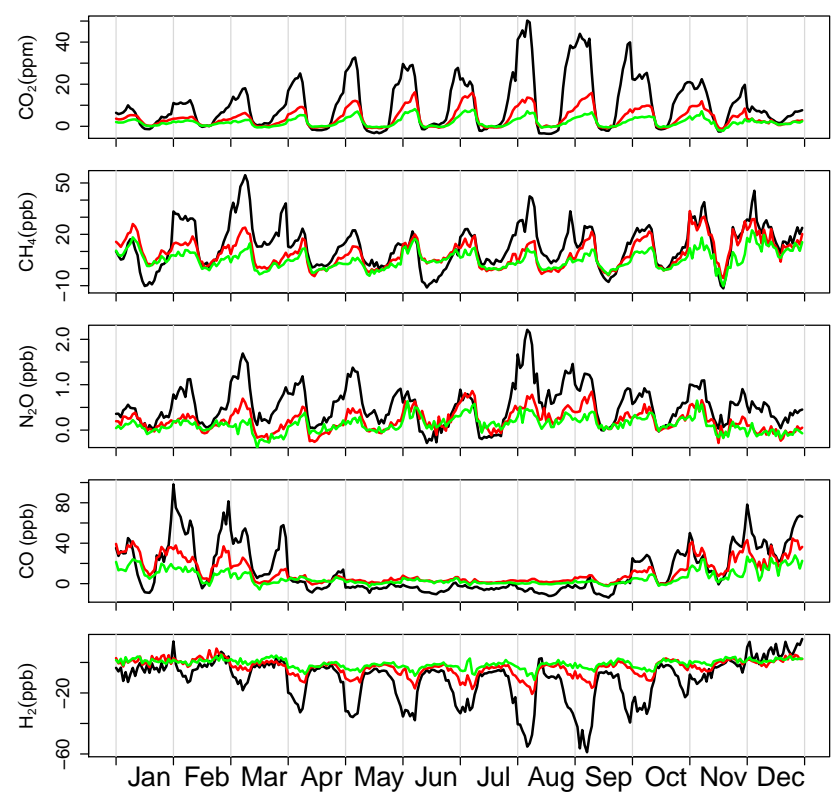

Figure 8. Vertical gradient of the mean diurnal cycles between the 5 and $180 \mathrm{~m}$ sampling level (black), the 50 and $180 \mathrm{~m}$ sampling level (red) and the 100 and $180 \mathrm{~m}$ sampling level (green) for $\mathrm{CO}_{2}, \mathrm{CH}_{4}$, $\mathrm{N}_{2} \mathrm{O}, \mathrm{CO}$ and $\mathrm{H}_{2}$.

when vertical mixing is strong, the gradients between the different levels are small.

Amplitudes of the diurnal variation and also nighttime gradients between sampling levels are largest between May and October for $\mathrm{CO}_{2}$ mole fractions. The largest diurnal variations are observed on the sampling level closest to the ground and therefore close to local sources, but we still observe small diurnal cycles of $\mathrm{CO}_{2}$ mole fractions at the $180 \mathrm{~m}$ sampling height as the nocturnal boundary layer is sometimes above $180 \mathrm{~m}$. Also, $\mathrm{CO}_{2}$ accumulated during nighttime below the $180 \mathrm{~m}$ sampling height can be observed as a small peak in the late morning, when vertical mixing starts and increases. A maximum gradient between the $5 \mathrm{~m}$ level and the $180 \mathrm{~m}$ level (see Fig. 8) of 30 to $50 \mathrm{ppm} \mathrm{CO}_{2}$ is reached at 05:00 GMT when the nocturnal boundary layer is below $180 \mathrm{~m}$. The $\mathrm{CO}_{2}$ gradients between 180 and $100 \mathrm{~m}$, and $180 \mathrm{~m} 50 \mathrm{~m}$ sampling lines are approximately 5 and $10 \mathrm{ppm}$, respectively. In the afternoon, 12:00 to 16:00 GMT, the monthly mean $\mathrm{CO}_{2}$ mole fractions of the sampling levels between 50 and $180 \mathrm{~m}$ agree within $0.5 \mathrm{ppm}$ from March to November and within $1 \mathrm{ppm}$ during the winter months (December to February), respectively.

During spring and summer at the Cabauw and Bialystok tall towers, Vermeulen et al. (2011) and Popa et al. (2010) observed lower daytime $\mathrm{CO}_{2}$ mole fractions at the lower sampling heights compared to the highest sampling heights due to local $\mathrm{CO}_{2}$ net uptake. Even though the Trainou tower is surrounded by forest, we have not observed lower daytime $\mathrm{CO}_{2}$ mole fractions in the mean gradients for spring or summer at the lower levels. 
The mean diurnal variation of the $\mathrm{CH}_{4}$ mole fraction show similar patterns as for $\mathrm{CO}_{2}$, with a stratification of the different sampling levels during nighttime. However, the amplitude of the $5 \mathrm{~m}$ level is less distinctive, indicating weaker local emissions compared to $\mathrm{CO}_{2}$. The nighttime $\mathrm{CH}_{4}$ gradients between 180 and $100 \mathrm{~m}$, and 180 and $5 \mathrm{~m}$ sampling level are approximately 30 and $15 \mathrm{ppb}$ respectively. The afternoon values of all sampling levels agree within 1-2 ppb.

At Trainou tower, the mean diurnal cycle amplitudes for $\mathrm{N}_{2} \mathrm{O}$ are approximately $0.5 \mathrm{ppb}$ for the 50,100 and $180 \mathrm{~m}$ sampling levels. During February, March, April, August and September, the $5 \mathrm{~m}$ sampling level clearly shows accumulation of $\mathrm{N}_{2} \mathrm{O}$ during nighttime, which corresponds to large $\mathrm{N}_{2} \mathrm{O}$ emissions from arable land shown by Lopez et al. (2012) for the catchment area of Trainou.

$\mathrm{SF}_{6}$ shows only a weak diurnal cycle without accumulation during nighttime. No significant gradient built up between the 50, 100 and $180 \mathrm{~m}$ sampling levels. Peaks shown in Fig. 7 can be attributed to single $\mathrm{SF}_{6}$ "events".

CO shows a noticeable seasonal behaviour, with large diurnal cycles and vertical gradients between October and March and very small diurnal cycles between April and September with small vertical gradients, also during nighttime.

For $\mathrm{H}_{2}$, in winter, there is almost no difference between the three heights $(50,100,180 \mathrm{~m})$ whereas in summer, due to the $\mathrm{H}_{2}$ uptake by soil, the gradient can reach up to $20 \mathrm{ppb}$ between the 50 and the $180 \mathrm{~m}$ inlet and even up to $60 \mathrm{ppb}$ between the 5 and the $180 \mathrm{~m}$ line. With the soil sink predominating during nighttime, when the boundary layer is low and the emissions reduced, the lowest mixing ratios are encountered at $5 \mathrm{~m}$. A more detailed analysis of $\mathrm{H}_{2}$ and $\mathrm{CO}$ is presented by Yver et al. (2011).

\section{Conclusions}

A new fully automated measurement system to analyse simultaneously atmospheric $\mathrm{CO}_{2}, \mathrm{CH}_{4}, \mathrm{~N}_{2} \mathrm{O}, \mathrm{SF}_{6}, \mathrm{CO}$ and $\mathrm{H}_{2}$ was installed on a $200 \mathrm{~m}$ transmission tower at Trainou in the Orléans forest. The station was installed in summer 2006 starting with a $\mathrm{CO}_{2}$ analyser and a $\mathrm{GC}$ system for $\mathrm{CH}_{4}, \mathrm{~N}_{2} \mathrm{O}$ and $\mathrm{SF}_{6}$ and consecutively upgraded with new instrumentation for $\mathrm{CO}$ and $\mathrm{H}_{2},{ }^{222} \mathrm{Rn}$ analysis and ${ }^{14} \mathrm{CO}_{2}$ sampling. After some logistical problems in the starting phase of the installation, the station has delivered high quality measurements fulfilling the requirements of the WMO recommendations. In June 2012, the electron capture detector developed a leak and therefore we had to close the station for some months and to take out of service the GC system. In June 2013, the station was upgraded with a CRDS analyser (G2401, Picarro Inc.) to measure $\mathrm{CO}_{2}, \mathrm{CH} 4$ and $\mathrm{CO}$, and in 2015 a second CRDS analyser for $\mathrm{N}_{2} \mathrm{O}$ will be added. The CARIBOU system will continue to be in service in order to have more than one year of overlap between the different analysers. The new instrumentation will have the advantage of requiring less maintenance than the GC system. In recent years the maintenance of the GC, operated remotely with 10 service visits per year, was quite time consuming taking into account the $180 \mathrm{~km}$ distance between Trainou and our laboratory in Gif-sur-Yvette.

Acknowledgements. The authors wish to thank Laurent Jourd'Heuil and Philippe Galdemar for their help in the management of the project and the development of the CARIBOU at the starting phase. We wish to thank Anne Royer and Adrien Royer for their help during the installation of the equipment at the Trainou tower.

This work was funded by a number of funding agencies; the European Union under the projects CHIOTTO (EVK2-CT-200200163) and CARBOEUROPE-IP (GOCE-CT-2003-505572), the French national project ANR N-TWO-O, CNRS/INSU and by CEA.

Edited by: G. Phillips

\section{References}

Bakwin, P. S., Tans, P. P., Hurst, D. F., and Zhao, C. L.: Measurements of carbon dioxide on very tall towers: results of the NOAA/CMDL program, Tellus B, 50, 401-415, doi:10.1034/j.1600-0889.1998.t01-4-00001.x, 1998.

Biraud, S., Ciais, P., Ramonet, M., Simmonds, P., Kazan, V., Monfray, P., O’Doherty, S., Spain, T. G., and Jennings, S. G.: European greenhouse gas emissions estimated from continuous atmospheric measurements and radon 222 at Mace Head, Ireland, J. Geophys. Res.-Atmos., 105, 1351-1366, doi:10.1029/1999jd900821, 2000.

Biraud, S., Ciais, P., Ramonet, M., Simmonds, P., Kazan, V., Monfray, P., O’Doherty, S., Spain, G., and Jennings, S. G.: Quantification of carbon dioxide, methane, nitrous oxide and chloroform emissions over Ireland from atmospheric observations at Mace Head, Tellus B, 54, 41-60, doi:10.1034/j.16000889.2002.00228.x, 2002.

Cundari, V., Colombo, T., Papini, G., Benedicti, G., and Ciattaglia, L.: Recent Improvements on Atmospheric $\mathrm{CO}_{2}$ Measurements at Mt-Cimone Observatory, Italy, Nuovo Cimento C, 13, 871-882, doi:10.1007/Bf02512003, 1990.

Da Costa, G. and Steele, L. P.: A low-flow analyser system for making measurements of atmospheric $\mathrm{CO}_{2}$, in: Report of the Ninth WMO Meeting of Experts on Carbon Dioxide concentration and Related Tracer Measurement Techniques, World Meteorological Organization, Geneva, 16-20, 1997.

Dlugokencky, E. J., Myers, R. C., Lang, P. M., Masarie, K. A., Crotwell, A. M., Thoning, K. W., Hall, B. D., Elkins, J. W., and Steele, L. P.: Conversion of NOAA atmospheric dry air $\mathrm{CH}_{4}$ mole fractions to a gravimetrically prepared standard scale, J. Geophys. Res.-Atmos., 110, D18306, doi:10.1029/2005jd006035, 2005.

Gaudry, A., Kanakidou, M., Mihalopoulos, N., Bonsang, B., Bonsang, G., Monfray, P., Tymen, G., and Nguyen, B. C.: Atmospheric Trace Compounds at a European Coastal Site - Application to $\mathrm{CO}_{2}, \mathrm{CH}_{4}$ and Cos Flux Determinations, Atmos. Envi- 
ron. A-Gen., 26, 145-157, doi:10.1016/0960-1686(92)90267-O, 1992.

Geels, C., Gloor, M., Ciais, P., Bousquet, P., Peylin, P., Vermeulen, A. T., Dargaville, R., Aalto, T., Brandt, J., Christensen, J. H., Frohn, L. M., Haszpra, L., Karstens, U., Rödenbeck, C., Ramonet, M., Carboni, G., and Santaguida, R.: Comparing atmospheric transport models for future regional inversions over Europe - Part 1: mapping the atmospheric $\mathrm{CO}_{2}$ signals, Atmos. Chem. Phys., 7, 3461-3479, doi:10.5194/acp-7-3461-2007, 2007.

Gloor, M., Bakwin, P., Hurst, D., Lock, L., Draxler, R., and Tans, P.: What is the concentration footprint of a tall tower?, J. Geophys. Res.-Atmos., 106, 17831-17840, doi:10.1029/2001jd900021, 2001.

Hall, B. D., Dutton, G. S., and Elkins, J. W.: The NOAA nitrous oxide standard scale for atmospheric observations, J. Geophys. Res.-Atmos., 112, D09305, doi:10.1029/2006jd007954, 2007.

Haszpra, L., Barcza, Z., Bakwin, P. S., Berger, B. W., Davis, K. J., and Weidinger, T.: Measuring system for the long-term monitoring of biosphere/atmosphere exchange of carbon dioxide, J. Geophys. Res.-Atmos., 106, 3057-3069, doi:10.1029/2000jd900600, 2001.

Jordan, A. and Steinberg, B.: Calibration of atmospheric hydrogen measurements, Atmos. Meas. Tech., 4, 509-521, doi:10.5194/amt-4-509-2011, 2011.

Levin, I., Münnich, K. O., and Weiss, W.: The effect of anthropogenic $\mathrm{CO}_{2}$ and ${ }^{14} \mathrm{C}$ sources on the distribution of ${ }^{14} \mathrm{CO}_{2}$ in the atmosphere, Radiocarbon, 22, 379-391, 1980.

Lopez, M., Schmidt, M., Yver, C., Messager, C., Worthy, D., Kazan, V., Ramonet, M., Bousquet, P., and Ciais, P.: Seasonal variation of $\mathrm{N}_{2} \mathrm{O}$ emissions in France inferred from atmospheric $\mathrm{N}_{2} \mathrm{O}$ and Rn-222 measurements, J Geophys. Res.-Atmos., 117, D14103, doi:10.1029/2012jd017703, 2012.

Masarie, K. A. and Tans, P. P.: Extension and Integration of Atmospheric Carbon-Dioxide Data into a Globally Consistent Measurement Record, J. Geophys. Res.-Atmos., 100, 11593-11610, doi:10.1029/95jd00859, 1995.

Messager, C.: Balancing of regional greenhouse gases fluxes from atmospheric measurements, Univ. Paris 7, Paris, 176 pp., 2007.

Messerschmidt, J., Geibel, M. C., Blumenstock, T., Chen, H., Deutscher, N. M., Engel, A., Feist, D. G., Gerbig, C., Gisi, M., Hase, F., Katrynski, K., Kolle, O., Lavrič, J. V., Notholt, J., Palm, M., Ramonet, M., Rettinger, M., Schmidt, M., Sussmann, R., Toon, G. C., Truong, F., Warneke, T., Wennberg, P. O., Wunch, D., and Xueref-Remy, I.: Calibration of TCCON column-averaged $\mathrm{CO}_{2}$ : the first aircraft campaign over European TCCON sites, Atmos. Chem. Phys., 11, 10765-10777, doi:10.5194/acp-11-10765-2011, 2011.

Pal, S., Xueref-Remy, I., Ammoura, L., Chazette, P., Gibert, F., Royer, P., Dieudonné, E., Dupont, J.-C., Haeffelin, M., Lac, C., Lopez, M., Morille, Y., and Ravetta, F.: Spatio-temporal variability of the atmospheric boundary layer depth over the Paris agglomeration: An assessment of the impact of the urban heat island intensity, Atmos. Environ., 63, 261-275, 2012.

Pal, S., Lopez, M., Schmidt, M., Ramonet, M., Gibert, F., XuerefRemy, I., and Ciais, P.: Investigation of the atmospheric boundary layer depth variability and its impact on the $222 \mathrm{Rn}$ concentration at a rural site, J. Geophys. Res.-Atmos., submitted, 2014.
Popa, M. E., Gloor, M., Manning, A. C., Jordan, A., Schultz, U., Haensel, F., Seifert, T., and Heimann, M.: Measurements of greenhouse gases and related tracers at Bialystok tall tower station in Poland, Atmos. Meas. Tech., 3, 407-427, doi:10.5194/amt-3-407-2010, 2010.

Ramonet, M. and Monfray, P.: $\mathrm{CO}_{2}$ baseline concept in 3D atmospheric transport models, Tellus B, 48, 502-520, doi:10.1034/j.1600-0889.1996.t01-2-00008.x, 1996.

Schmidt, M., Glatzel-Mattheier, H., Sartorius, H., Worthy, D. E., and Levin, I.: Western European $\mathrm{N}_{2} \mathrm{O}$ emissions: A top-down approach based on atmospheric observations, J. Geophys. Res.Atmos., 106, 5507-5516, doi:10.1029/2000jd900701, 2001.

Schmidt, M., Graul, R., Sartorius, H., and Levin, I.: The Schauinsland $\mathrm{CO}_{2}$ record: 30 years of continental observations and their implications for the variability of the European $\mathrm{CO}_{2}$ budget, $\mathrm{J}$. Geophys. Res.-Atmos., 108, 4619, doi:10.1029/2002jd003085, 2003.

Stephens, B. B., Gurney, K. R., Tans, P. P., Sweeney, C., Peters, W., Bruhwiler, L., Ciais, P., Ramonet, M., Bousquet, P., Nakazawa, T., Aoki, S., Machida, T., Inoue, G., Vinnichenko, N., Lloyd, J., Jordan, A., Heimann, M., Shibistova, O., Langenfelds, R. L., Steele, L. P., Francey, R. J., and Denning, A. S.: Weak northern and strong tropical land carbon uptake from vertical profiles of atmospheric $\mathrm{CO}_{2}$, Science, 316, 1732-1735, doi:10.1126/science.1137004, 2007.

Stohl, A., Forster, C., Frank, A., Seibert, P., and Wotawa, G.: Technical note: The Lagrangian particle dispersion model FLEXPART version 6.2, Atmos. Chem. Phys., 5, 2461-2474, doi:10.5194/acp-5-2461-2005, 2005.

Thompson, R. L., Manning, A. C., Gloor, E., Schultz, U., Seifert, T., Hänsel, F., Jordan, A., and Heimann, M.: In-situ measurements of oxygen, carbon monoxide and greenhouse gases from Ochsenkopf tall tower in Germany, Atmos. Meas. Tech., 2, 573591, doi:10.5194/amt-2-573-2009, 2009.

Thoning, K. W., Tans, P. P., and Komhyr, W. D.: Atmospheric Carbon-Dioxide at Mauna Loa Observatory .2. Analysis of the Noaa Gmcc Data, 1974-1985, J. Geophys. Res.-Atmos., 94, 8549-8565, doi:10.1029/Jd094id06p08549, 1989.

Vermeulen, A. T., Schmidt, M., Manning, A., Moors, E., Moncrieff, J., Haszpra, L., Stefani, P., and Lindroth, A.: CHIOTTO, Final Report ECN, PettenECN-E-07-052, 118, 2007.

Vermeulen, A. T., Hensen, A., Popa, M. E., van den Bulk, W. C. M., and Jongejan, P. A. C.: Greenhouse gas observations from Cabauw Tall Tower (1992-2010), Atmos. Meas. Tech., 4, 617644, doi:10.5194/amt-4-617-2011, 2011.

Whittlestone, S. and Zahorowski, W.: Baseline radon detectors for shipboard use: Development and deployment in the First Aerosol Characterization Experiment (ACE 1), J. Geophys. Res.-Atmos., 103, 16743-16751, doi:10.1029/98jd00687, 1998.

Yver, C., Schmidt, M., Bousquet, P., Zahorowski, W., and Ramonet, M.: Estimation of the molecular hydrogen soil uptake and traffic emissions at a suburban site near Paris through hydrogen, carbon monoxide, and radon-222 semicontinuous measurements, J. Geophys. Res.-Atmos., 114, D18304, doi:10.1029/2009jd012122, 2009.

Yver, C., Schmidt, M., Bousquet, P., and Ramonet, M.: Measurements of molecular hydrogen and carbon monoxide on the Trainou tall tower, Tellus B, 63, 52-63, doi:10.1111/j.16000889.2010.00520.x, 2011. 
Zahorowski, W., Chambers, S. D., and Henderson-Sellers, A.: Ground based radon-222 observations and their application to atmospheric studies, J. Environ. Radioactiv., 76, 3-33, doi:10.1016/j.jenvrad.2004.03.033, 2004.
Zhao, C. L. and Tans, P. P.: Estimating uncertainty of the WMO mole fraction scale for carbon dioxide in air, J. Geophys. Res.Atmos., 111, D08S09, doi:10.1029/2005jd006003, 2006. 